\title{
Fusion, gene misexpression and homeotic transformations in vertebral development of the gnathostome stem group (Placodermi)
}

\author{
ZERINA JOHANSON* ${ }^{*}$, ROBERT CARR $^{2}$ and ALEX RITCHIE ${ }^{3}$ \\ ${ }^{1}$ Department of Palaeontology, Natural History Museum, London, UK, ${ }^{2}$ Department of Biological Sciences, \\ Irvine Hall, Ohio University, Athens, OH, USA and ${ }^{3}$ Australian Museum, Sydney, NSW, Australia
}

\begin{abstract}
Development of the vertebral column is controlled by a complex of pleiotropic and polygenetic phenomena, in the mouse and chick regulating formation of different parts of individual vertebrae and morphological identity along the column ('Hox code'). In mouse and chick, experimental misexpression, including upstream and downstream genes, results in shifts in vertebral identity, loss of particular parts of individual vertebrae or vertebral fusion. Axial skeleton homologies across the Vertebrata allow these observations to be extended to taxa such as Homo sapiens, Chondrichthyes and Placodermi, the latter an entirely fossil group. Misexpression phenotypes among fossil taxa illuminate the phylogenetic history of these regulatory mechanisms. Phenotypes associated with genes originating via genomic duplication can determine the historical depth for these duplication events. Analysis of an ontogenetic sequence for the occipital-synarcual complex in the placoderm Cowralepis mclachlani provides the basis for comparison of this early gnathostome with other placoderms, chondrichthyans and amniotes. The occipital-synarcual patterns in placoderms parallel the phenotypic misexpression in mice and chicks (fusion and homeotic mutation) and the varying degrees of fusion in the Type I-III human Klippel-Feil syndrome. The association of these phenotypes to Hoxd regulatory complexes indicates that the gnathostome genomic duplication occurred at the base of the gnathostome stem group. Given the conservative nature of regulatory genes and the homology of vertebral elements, the presence of fusion in stem gnathostomes implies that the mechanism of fusion in mouse and chick models can be extrapolated to extant chondrichthyans (testable) and accounts for the phenotypic similarity across gnathostomes. The presence of these phenotypes in fossils indicates the antiquity of these regulatory mechanisms and of genomic duplication.
\end{abstract}

KEY WORDS: vertebral column, Placodermi, Hox gene, misexpression

The Placodermi are extinct jawed vertebrates resolved phylogenetically to the base of the jawed vertebrate clade, basal to the crown-group Gnathostomata (Chondrichthyes + Osteichthyes; Donoghue and Purnell, 2005; Fig. 1). As such, placoderms represent the initial jawed vertebrate radiation and are crucial for determining the major evolutionary changes between jawless and jawed vertebrates. As argued below, this can include inferences on the genes or processes involved in the development of particular features, even though the Placodermi are only known from fossils (cf. Donoghue and Purnell, 2005). We focus on the craniocervical region, comprising the occipital region of the braincase and anterior vertebral column, and genes involved in devel- opment of the vertebral column, including Pax-1, Gli-3, Zic, Msx1, Msx-2 as well as Hox genes and the upstream genes regulating these (Kessel et al., 1990; Lufkin et al., 1992; Condie and Cappechi, 1993, 1994; Monsoro-Burq et al., 1994; Wallin et al., 1995; Watanabe et al., 1998; Peters et al., 1999; Christ et al., 2000; Storre et al., 2002; van den Akker et al., 2002; MonsoroBurq, 2005).

These genes have been studied primarily in mice and chickens, but homologies in the vertebral column can be identified across the Vertebrata (Wellik, 2007; Fig. 1, mice and chickens are included in the clade Osteichthyes). The occipital region of the braincase and the vertebral column can be considered serial

\footnotetext{
*Address correspondence to: Zerina Johanson. Department of Palaeontology, Natural History Museum, Cromwell Road, London, SW7 5BD UK. Fax: +44-20-7942-5546. e-mail: z.johanson@nhm.ac.uk
} 
homologues, as they develop from consecutive post-otic somites (sclerotome; Kuratani, 2005). Both have a deep phylogenetic history within the Vertebrata. With respect to the vertebral column, neural and haemal elements dorsal and ventral to the unrestricted notochord, respectively, represent the primitive homologous pattern for the clade (Arratia et al., 2001; Grotmol et al., 2003). For example, the lamprey vertebral column consists of disorganized elements resting above the notochord; these are identified as neural arches and homologised with other vertebrate neural arches (Janvier, 1996; Kardong, 2002). Other jawless vertebrates also possess these dorsal elements, including the fossil groups Heterostraci and Osteostraci (Fig. 1; Janvier, 1996). Dorsal arches are also present in the fossil jawless vertebrate Euphanerops, and ventral vertebral elements, or haemal arches, appear for the first time in vertebrate evolution, in this taxon (Janvier and Arsenault, 2007). The placoderm vertebral column, for example, in Cowralepis (Ritchie, 2005) is also characterised by these dorsal and ventral elements. Therefore, if misexpression of a particular gene affects the neural arches in the mouse or chick vertebra (e.g., Zic, Gli-3, Monsoro-Burq, 2005), homology to other vertebrate neural arches, as axial elements dorsal to the notochord, suggest this gene was involved in the development of these neural arches as well.

Homologous regions of the vertebral column can also be recognized relative to anterior expression boundaries of $\mathrm{Hox}$ genes. For example, Hoxc6 boundaries designate an anterior cervical region of the vertebral column in zebrafish, mice and chickens, regardless of how many vertebrae are included or whether modified atlas and axis vertebra are present (mice) or not (zebrafish; Burke et al., 1995). This is relevant to our discussion below on effects of Hox misexpression on the anterior vertebrae of mice (atlas) compared to the unusual morphology we observed in the synarcual (anterior vertebral column) and occipital of Cowralepis mclachlani.

The occipital and the synarcual of several placoderm taxa are considered below, including Cowralepis mclachlani(Ritchie, 2005). The synarcual is located just posterior to the occipital and is derived in most cases from the neural and/or haemal arches. The synarcual is known from only a small number of taxa within the Placodermi as well as in the Chondrichthyes (Holocephali (chimera), Batoidea (skates, rays)), and is formed by the fusion of these vertebral elements. Among placoderms, varying degrees of synarcual fusion can occur, with some aspects of vertebral morphology being retained, such as distinct neural arches and spines (Stensiö, 1963; Miles and Young, 1977; Long, 1997). Moreover, the synarcual can be composed of various parts of the vertebrae: in certain taxa, neural arches and spines can be recognized as contributing to the synarcual, but in taxa such as Cowralepis, only arch bases or pedicles contribute ('arcualia', described further below). This relates to the varying contribution of sclerotomal regions to different parts of the vertebrae, as seen in mice and chickens, where dorsal and ventral regions are under the control of different genes, such as Msx-1 and Msx-2, and Pax1 respectively (Monsoro-Burq et al., 1994; Watanabe et al., 1998).

Despite being derived from consecutive post-otic somites, the morphology of the occipital region of the braincase and the synarcual generally differs in both placoderms and chondrichthyans (Denison, 1978; Bemis and Forey, 2001; Figs. 2 L,M, 3). An exception to this is seen in Cowralepis, where the occipital and

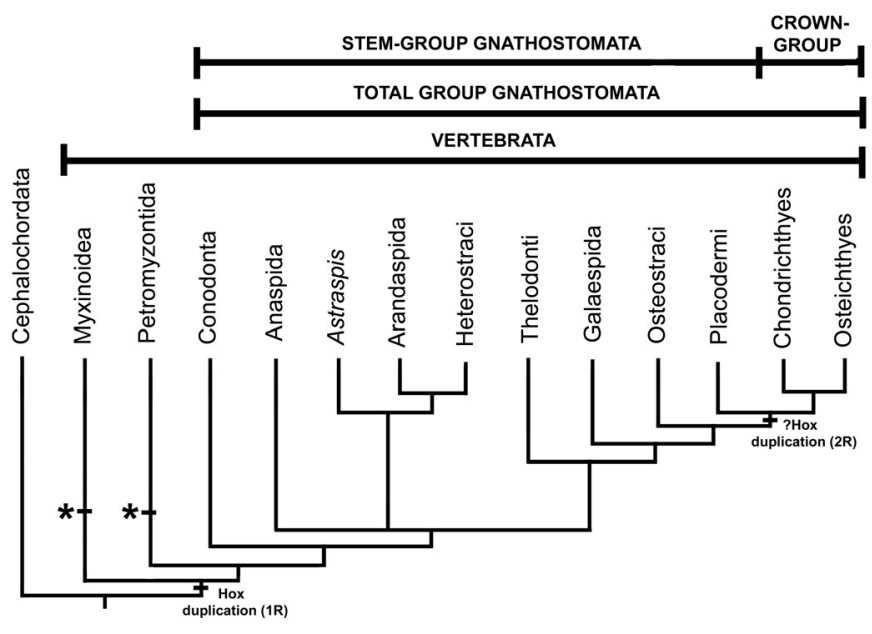

Fig. 1. Cladogram showing relationships of the Vertebrata and proposed Hox gene cluster duplication within the stem-group Gnathostomata. Adapted from Donoghue and Purnell (2005). Asterisk associated with hagfish (Myxinoidea) and lamprey (Petromyzontida) lineages indicates additional, but independent (with respect to the totalgroup Gnathostomata) Hox duplication events, and additionally deletion in lampreys.

synarcual are almost identical in later ontogenetic stages (Fig. 2 A-J). As discussed further below, this morphological similarity, as well as the varying degrees of vertebral fusion in the synarcual, compares to the effects of certain human disease syndromes on the anterior, cervical vertebrae and to morphologies generated experimentally in the cervical vertebrae of mice through gene misexpression or deletion. Comparison of these to placoderm morphologies allows us to consider the involvement of these genes deeper in vertebrate history, among the Placodermi and the stem-Gnathostomata. Notably, hypotheses developed below are ultimately testable in extant chondrichthyans possessing a synarcual.

\section{Results}

\section{Occipital and synarcual development in Cowralepis mclachlani}

Cowralepis mclachlani (Phyllolepidae; Arthrodira) was described from the Late Devonian Merriganowry Shale near Merriganowry, New South Wales, Australia (Ritchie, 2005). Specimens have been collected for several years from a fish-bearing sequence at least 25 meters thick, and from hundreds of bedding planes within this unit (Ritchie, 2005; Carr et al., 2009). The shale is very fine-grained and preserves the fossil fishes in substantial detail, through a range of ontogenetic stages (limited to the sequence of perichondral ossification in these fossil specimens, around preexisting cartilaginous elements; Fig. 2 A-K). These ontogenetic stages show the development of the occipital region, at the rear of the braincase, as well as the synarcual.

In the earliest ontogenetic stages preserved for Cowralepis mclachlani, the occipital and synarcual are not visible, but as noted above, were present as cartilaginous condensations. These condensations are not preserved, so we have no information as to which element developed first, or whether they developed at 
the same time. In a larger specimen, perichondral ossification has begun, and both the occipital and synarcual are preserved, although the occipital has been distorted somewhat postmortem, with the opposing half of the element missing (occ, Fig. 2 A,B, ventral view). The synarcual (syn) is separated from the occipital, which may have also occurred after death. Alternatively, this separation could be real, indicating the presence of cartilaginous and unpreserved regions of the occipital and synarcual. As discussed further below, perichondral ossification of the occipital occurs anteriorly and posteriorly (e.g., Fig. 2 C-E,J), and a thicker bony joint is eventually formed between the occiput and the synarcual in later stages (e.g., Fig. 2 E,F,I-K). Although this alternative suggests that an ossified functional joint between the occipital and synarcual did not exist until later in ontogeny, this may not be necessary, since a joint is present between the bony plates of the head and trunkshield, even in early stages (Ritchie, 2005).

Nevertheless, the 'waisted' or hourglass-shaped morphology of the occipital seen in larger specimens is already present at this early ontogenetic stage. Individual vertebral elements can be seen medially, within the 'waisted' region of the occipital, indicating that vertebrae are added to the original occipital, as is common in placoderms (Stensiö, 1963; Bemis and Forey, 2001; Fig. 2B, arrow). These vertebrae are represented by disc-shaped elements comprising concentric circles, comparable to the bases (pedicles) of the neural and haemal arches in the axial skeleton of Cowralepis (Ritchie, 2005). Because the majority of Cowralepis specimens illustrated are in ventral view (i.e., the internal surface of the headshield is visible; Fig. $2 \mathrm{~A}-\mathrm{K}$ ), the visible disc-shaped elements would represent the ventrally oriented neural arch
Fig. 2. Synarcual development in Cowralepis mclachlani and Chimera monstrosa. (A-K) Cowralepis mclachlani. (A,B,B') AMF 129164, ventral view. (B, $\left.\mathbf{B}^{\prime}\right)$ Stereopair of occipital and synarcual regions. (C,D, $\left.\mathbf{D}^{\prime}\right)$ AMF 96785, ventral view. (D, '.') Stereopair of occipital region. (E,E') AMF96753, ventral view, stereopair of occipital and synarcual regions. (F,F') AMF 96751, ventral view, stereopair of occipital and synarcual regions. (G,H,H') AMF 96754, dorsal view. $\left(\mathbf{H}, \mathbf{H}^{\prime}\right)$ Stereopair of occipital region. (I,I') AMF96752, ventral view, stereopair of occipital and synarcual regions. (J) AMF132301, ventral view, occipital and synarcual regions. (K) AMF103673, ventral view, ventral view, occipital and synarcual regions. In (B), arrow indicates vertebral elements (neural arch bases) contributing to synarcual and occipital. In (D,E,J) arrows indicate perichondrally ossifying anterior border of occipital. In (F) arrows indicate diamond-shaped opening between two halves of occipital and synarcual. In (I) arrow indicates vertebral elements (neural arch bases) contributing to synarcual. (L,M) Chimera monstrosa, AMNH 55040, larger black arrows indicate anterior. (L) smaller arrow indicates region shown in (M). (M) Smaller arrows indicate individual vertebral elements added to rear of synarcual, enclosing foramina for spino-occipital nerves (seen as paired foramina more anteriorly). Abbreviations: AMF, Australian Museum, Sydney; AMNH, American Museum of Natural History, New York; d.sp, dorsal fin spine; occ, occipital; sp.can, foramina for spinooccipital nerves; syn, synarcual. Scale bar $(A-K), 1 \mathrm{~cm} ;(L, M), 0.5 \mathrm{~cm}$.
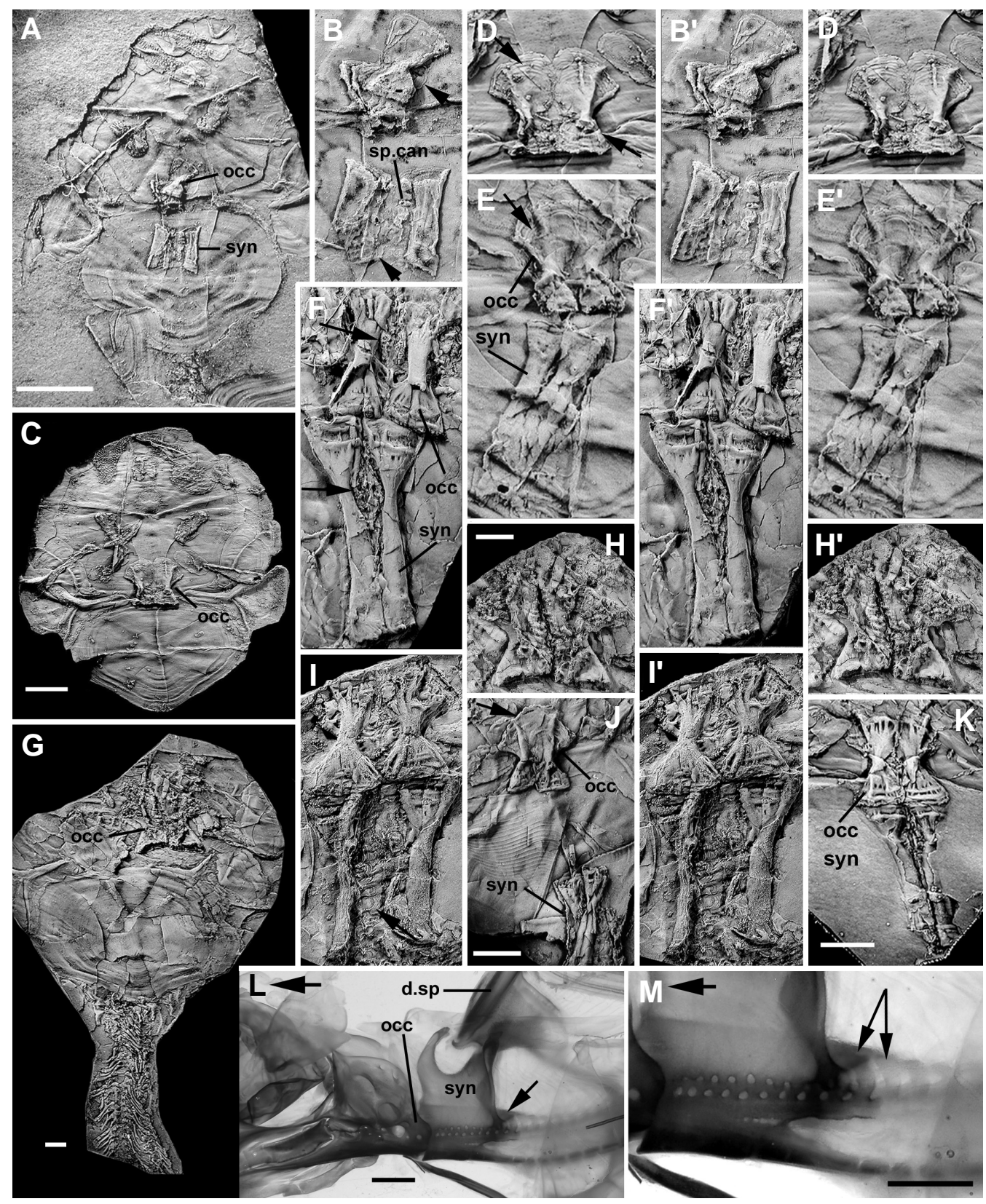
pedicles. The spino-occipital nerves would pass between these elements, although foramina indicating the exit of these nerves are not visible, possibly due to distortion.

The synarcual, in contrast, is initially rectangular in shape, with 4-6 canals for the spino-occipital nerves clearly visible (sp.can; Fig. 2B). The curved margins of the disc-shaped neural arch pedicles can also be seen, located between the spino-occipital nerve canals (Fig. 2B, arrow). Again, the foramina marking the exit of the spinal nerves along the synarcual cannot be seen. At these earlier developmental stages, the occiput and synarcual have different morphologies. In later stages, the synarcual also becomes waisted or spool-shaped, indicating a posterior morphological shift from occipital to synarcual (Fig. 2 E,F,I-K).

In Fig. 2 C,D (ventral view), the morphology of the occipital consists of two waisted halves giving an overall hourglass shape, separated by a small notch situated in the midline (synarcual lost from this specimen). The bone appears thin, although short, thick ridges extend anteriorly from the waisted region. The anterior half of each hourglass is larger and expands anteriorly to a rounded margin. Distinct curved lines are visible anteriorly, and comparable, but transverse, lines are present posteriorly. We suggest these lines indicate ongoing perichondral ossification of the occipital. The posterior lines are lost on what are believed to be older individuals (based on size and degree of bone development), although the curved anterior margin of the occipital is still present (compare Fig. 2D with Fig. $2 \mathrm{E}, \mathrm{J}$ ). On the older specimens, the posterior margin of the occipital appears thicker and more robust. Absence of the transverse lines combined with the thicker posterior margin indicates that perichondral ossification has ceased (although remodeling and mineralization of the cartilage may continue), and from this point a functional bony joint between the occiput and synarcual develops.

The occipital and synarcual are more rarely preserved in dorsal view, with the synarcual particularly showing the same smooth surface dorsally as ventrally (Ritchie, 2005). This indicates that the more dorsal parts of the neural arch (above the pedicle) and neural spine (as seen in typical trunk vertebrae) are not incorporated into the bony synarcual, and may have never developed. This is less clear in the occipital (Fig. $2 \mathrm{G}, \mathrm{H}$ ), where spino-occipital nerves canals are visible and bounded on both sides by a high ridge (stereopair, Fig. $2 \mathrm{H}, \mathrm{H}^{\prime}$ ). These ridges could represent fused neural arch and spines; however, the ridges appear to diverge anteriorly, suggesting that the span of the neural arch elements decreased in size from anterior to posterior, which seems unlikely. Therefore, we suggest these ridges represent a thickening of bone and that like the synarcual (Ritchie, 2005), neural arch and spine elements are not associated with the vertebrae that have been incorporated into the occipital.

As growth continues, the occipital and synarcual become strongly spool-shaped, with thicker bone overall and particularly at the anterior and posterior ends where the bone takes the form of supporting struts (Fig. $2 \mathrm{~F}, \mathrm{I}, \mathrm{K})$. At this point in development, the occipital and synarcual are almost identical in morphology, although the synarcual is most strongly spool-shaped anteriorly, while the posterior part of the synarcual articulates posteriorly with the vertebral column. In ventral view, the composition of the synarcual is once again indicated by small, concentric circular areas extending along the length of the synarcual (Fig. 2I, arrow), comparable to the circular bases of the neural arches, as described above (Ritchie, 2005).

\section{Discussion}

Along with Cowralepis mclachlani, a synarcual is found in only a small number of placoderms, including Trematosteus, Beleosteus, Erromenosteus (Arthrodira; Fig. 3A), Gemuendina, Nefudina and Jagorina (Rhenanida; Fig. 3 C,C1) and Austroptyctodus (Ptyctodontida) (Stensiö, 1963; Miles and Young, 1977; Denison, 1978; Long, 1997; Lelièvre and Carr, 2009). The synarcual also occurs in certain chondrichthyans, including holocephalans (Fig. 2 L,M), skates and rays (de Beer, 1971; Didier, 1995; González-Isáis and Mones Dominguez, 2004; Fig. $3 \mathrm{~B}, \mathrm{D})$. In these chondrichthyans, the synarcual supports the dorsal fin and accompanying spine (d.sp, Fig. $2 \mathrm{~L}$ ) or the pectoral girdle and fin (Fig. 3D, pect). It is important to note that the synarcual and occipital remain morphologically distinct in all of these taxa.

In ptyctodont placoderms, the synarcual also supports the dorsal fin, but the neural spines included in the synarcual are incompletely fused (Miles and Young, 1977; Long, 1997). Neural
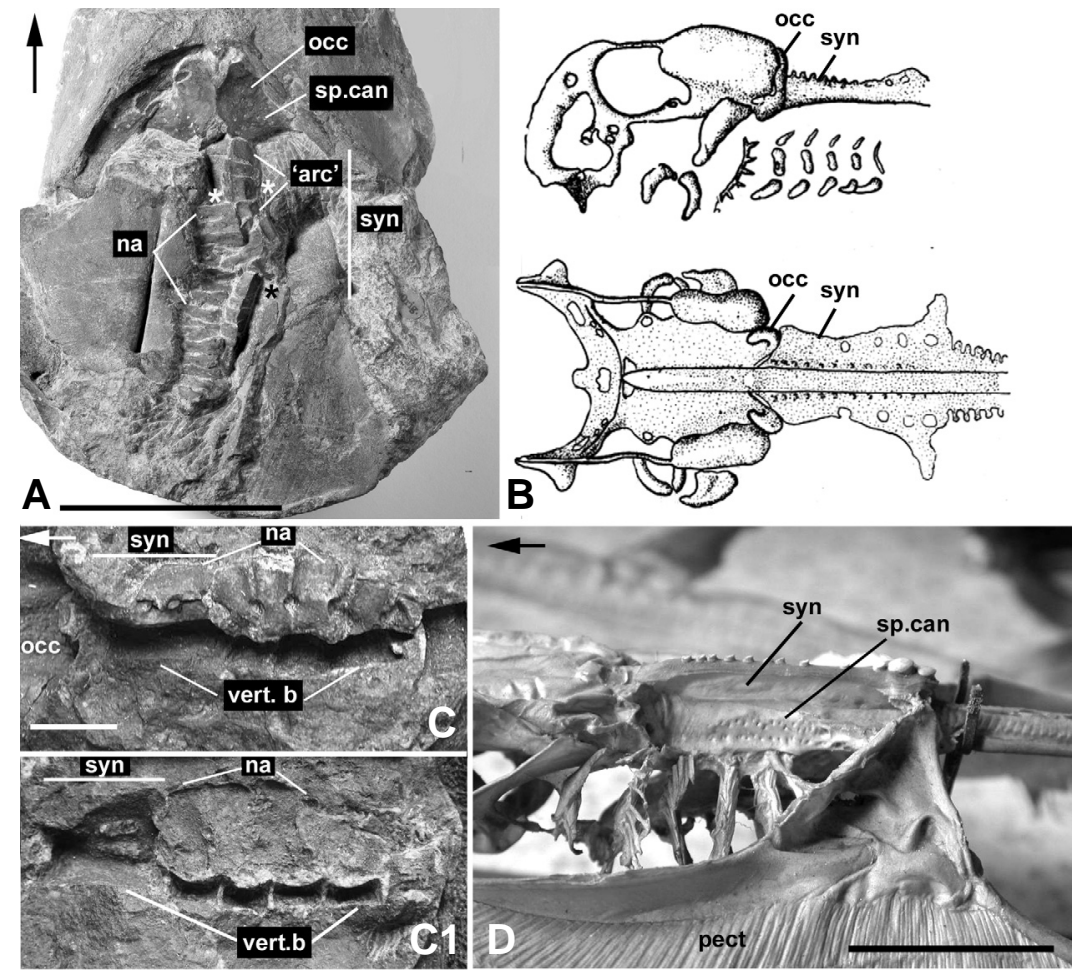

Fig. 3. Placoderm and chondrichthyan synarcuals. (A) Erromenosteus diensti (Stensiö, 1934), Mb.f. 114. (B) Torpedo ocellata Rafinesque, 1810. Adapted from de Beer (1971). (C,C1) Jagorina pandora Jaekel Mb.f 510.2, part and counterpart (the latter rotated 180 degrees so that (C,C1) have the same orientation). (D) Himantura uarnak (Sorley, 1933) Mb.f 22851. In (A,C,D) arrow indicates anterior. Abbreviations: 'arc', arcualia (equivalent to neural arch bases); Mb.f, Museum für Naturkunde, Berlin; na, neural arch; pect, pectoral fin; vert.b, vertebral bodies. Scale bar, $1 \mathrm{~cm}$. 
arch remnants are present in other placoderm synarcuals, including that of Erromenosteus (na, Fig. 3A), Jagorina (na, Fig. 3C) and Nefudina (Lelièvre and Carr, 2009). In the former taxa, fusion of vertebral elements within the synarcual is variable, with the arches remaining identifiable (syn, Fig. 3 A,C), while in Nefudina, there is a complete loss of individual arch identity. In Erromenosteus, the neural arch bases or 'arcualia' are also variably fused (Stensiö, 1963; 'arc', Fig. 3A, asterisk indicates area of fusion). In Jagorina, these arcualia are fused and lack individual identity within the synarcual, compared to more posterior vertebra (na, vert.b; Fig. 3C,C1). By comparison, the synarcual of Cowralepis and Trematosteus (Stensiö, 1963) is more completely fused and both lack neural spines dorsally. As described above, the synarcual of Cowralepis comprises neural and haemal arch pedicles alone, developing as in chondrichthyans, where the synarcual is formed by the fusion of the neural arches, which then fuse ventrally with haemal arch bases (Fig. 2M).

Vertebral elements themselves develop from somites derived from paraxial mesoderm. Within the somite, the dorsal dermomyotome gives rise to dermis of the back and the trunk muscles, while the ventral sclerotome contributes to the axial skeleton and ribs. In amniotes, including mice and chickens, the sclerotome itself is divided into anterior and posterior halves, with the medial portion of these halves forming the vertebral centra and intervertebral bodies, respectively (reviewed by MonsoroBurq, 2005). Neural arches, pedicles and ribs develop from the more lateral parts of the posterior half of the sclerotome, while the dorsal parts of the neural arches (neural spine, spinous process) develop from the dorsal sclerotome (Monsoro-Burq et al., 1994; Wallin et al., 1995; Watanabe et al., 1998; Peters et al., 1999; Christ et al., 2000; DiPaola et al., 2005).

Certain genes can be related to the development of different parts of the vertebra, with most research being conducted on easily manipulated laboratory animals such as mice and chickens. For example, the genes $M s x-1$ and $M s x-2$ are involved in the development of the neural spines (Monsoro-Burq et al., 1994; Monsoro-Burq, 2005), with the development of the more dorsal spines and ventral vertebral bodies involving an antagonistic feedback loop between Bmp-4 and Shh (Watanabe et al., 1998). When cells from the dorsal part of the sclerotome migrate between the superficial ectoderm and the roof plate of the neural tube, Bmp-4 is produced, which results in expression of $M s x-1$ and $M s x-2$ and development of cartilage. By comparison, Shh is produced ventrally, which induces Pax-1 expression. Ectopic expression of Shh or Bmp-4 results in downregulation of Msx-1 and $M s x-2$, and Pax-1, respectively. Interestingly, misexpression of Pax-1, although normally affecting the vertebral bodies, can also result in bridges of cartilage connecting neural arches $(\mathrm{Pe}-$ ters et al., 1999). Fusion of neural arches can also result from the misexpression of the genes Zic and Gli-3, affecting the dorsal parts of the vertebrae and the proximal ribs. In Gli-3\%-mice, neural arches of the cervical vertebrae were fused, while in double homozygous mice, $\mathrm{Zic}^{-/ /}$Gli-3/- mice, vertebral arches along the column were fused (Aruga et al., 1999). In the latter mutant mice, arches of cervical vertebrae were fused into a plate-like structure. Morphologies produced by the misexpression of these genes are comparable to the chondrichthyan and placoderm synarcual morphologies described above. For example, downregulation of $M s x-1$ and $M s x-2$ and loss of neural spines in mice could explain the near absence of neural arches and spines from the synarcual of taxa such as Cowralepis, while misexpression of Zic and Gli-3 could produce the fused neural arches seen in ptyctodont placoderms.

As well, several human disease syndromes, such as KlippelFeil syndrome, include the fusion of the anterior or cervical region of the vertebral column, to which the placoderm and chondrichthyan synarcual can again be compared (McGaughran et al., 2003; Matsuoka et al., 2005; Schaffer et al., 2005; Turnpenny et al., 2007). The variable fusion in the placoderm synarcual is similar to differing degrees of fusion seen in Types I-III human Klippel-Feil syndrome (Tracy et al., 2004; Samartzsis et al., 2006). In Type I Klippel-Feil syndrome, a single fused segment occurs (comparable to the single segment seen in Jagorina (Fig. $3 C$ )). In Types II and III human Klippel-Feil syndrome, multiple vertebrae are fused, with the fused segments being either non-contiguous or contiguous, the latter representing the greatest degree of fusion of the anterior vertebral column (Samartzsis et al., 2006). Type II could be compared to Erromenosteus (Fig. 3A), while the contiguous Type III Klippel-Feil is comparable to Cowralepis (Fig. 2 A-K; and Nefudina).

Causes of the vertebral fusion associated with Klippel-Feil syndrome include incomplete segmentation of the cervical vertebrae related to misexpression of Pax-1 or genes in the Notch signaling pathway (McGaughran et al., 2003; Tracy et al., 2004; Schaffer et al., 2005). However, recent studies link mutation in Notch genes with spondylocostal dysostosis, associated with abnormal vertebral segmentation and malformed vertebrae (Turnpenny et al., 2007), the latter not being a feature of synarcual development. Turnpenny et al. (2007: table 1) note that KlippelFeil syndrome may be related to Pax-1 misexpression. Pax-1 mutants in mice showed abnormal vertebral segmentation (McGaughran et al., 2003) and as noted above, fusion of neural arches via cartilaginous bridges (Wallin et al., 1995; Peters et al., 1999; Samartzsis et al., 2006). Other genes that may be involved in human disease syndromes such as Klippel-Feil include Zic and Gli-3, resulting in neural arch fusion when misexpressed. As more research on genes involved in these human syndromes occurs, results can be extended to the development of the synarcual, particularly in extant chondrichthyans. Of interest in this regard are recent attempts to apply studies on malformations in the teleost fish vertebral column to human disease syndromes (Gorman and Breden, 2007; supporting suggestions made above regarding vertebral homologies among the Vertebrata).

\section{Morphological shift between the occipital and synarcual of Cowralepis}

An unusual feature of Cowralepis is the similarity between the occipital and synarcual, with both developing two hourglass shaped halves and an overall spool-like morphology. As discussed below, we believe this represents the transformation of one body part into another, which is the definition of a homeotic change, as first described by Bateson (1894).

In placoderms generally, vertebral elements added to the rear of the occiput become incorporated into the braincase, obscuring original vertebral morphologies. This is the case in Erromenosteus (Fig. 3A) and other placoderms (Stensiö, 1963; Young, 1979; Bemis and Forey, 2001). Otherwise, little modification of the occiput occurs, such that the occipital and synarcual are morpho- 
logically distinct. Earlier ontogenetic stages of development or ossification in Cowralepis are characterised by this differing morphology, where the occipital halves have an hourglass or 'waisted' shape, and the synarcual a more rectangular shape (Fig. 2 A,B). The spool-shaped morphology characterises the synarcual in later ontogenetic stages, particularly anteriorly and in association with the bony joint between the occiput and synarcual. This suggests that during development there was a morphological shift from the occiput to the synarcual, such that the synarcual comes to resemble the occiput. This occurs not only anteriorly, where the joint forms between the synarcual and occipital, but also in the 'waisted', spool-shape of the two halves of the synarcual (particularly behind the joint region) and the roughly diamond-shaped open area between them ventrally (e.g., Fig. 2F, arrows).

Shifts in morphology during ontogeny occur frequently among animals, in response to external forces such as temperature changes, changes in diet and predation. For example, the body shape of the carp changes in response to predators such as the pike, by becoming more deep-bodied and so larger than the pike's gape (Brönmark and Miner, 1992). In the goldfish, these morphological changes are reversible. If goldfish are placed in an experimental environment with pike chemical signals, they will increase in size. If these cues are removed and then reintroduced, growth rates will slow and then increase again (Chivers et al. 2008). Jaw morphology in fish will change during ontogeny in response to the different types of food taken (Wintzer and Motta, 2005; Andersson et al. 2006). Mice exposed to extremes of temperature ( $\mathrm{Li}$ and Shiota, 1999) will show homeotic transformations of the vertebrae, including those involving the atlas and occipital region.

The first of these changes reflects the high degree of phenotypic plasticity present in these animals, but involves change or a shift from one type of morphology to a different morphology (e.g. narrower body to deeper body, different jaw morphologies). In Cowralepis, by comparison, one part of the body (synarcual) is transformed morphologically into another part of the body (occipital). This transformation could have occurred for functional reasons (e.g., increased support of headshield on trunkshield), but a similar transformation is not present in other placoderms possessing a synarcual, nor in chondrichthyans. The most important part of the occipital-synarcual complex, in functional terms, is the joint at which the two meet, so it would be expected that changes would involve this region alone, rather than the entire synarcual. As well, there is no indication that the Cowralepis synarcual shifts morphology again in later ontogenetic stages (pers. observation), in other words, that the morphological changes are not related to phenotypic plasticity. For these reasons, we suggest that these changes in Cowralepis are due to a homeotic transformation. With respect to the vertebral column, homeotic changes occur when Hox genes are misexpressed.

\section{Hox genes and homeotic transformation of the vertebral column}

Vertebral morphology and identity are determined by the anterior or rostral expression boundaries of several Hox genes. Hox genes show temporal and spatial collinearity, such that the morphology of the craniocervical joint and anterior vertebral column will be determined by the more 3' Hox genes (Burke et al., 1995; Favier and Dolle, 1997; Manley and Capecchi, 1997; Zákány et al., 2001; Deschamps and van Nes, 2005).
Misexpression or deletion of these genes causes shifts in morphology. For example, anterior misexpression of Hoxd-4 shifts the rostral boundary of gene expression posteriorly. In the mouse vertebral column this results in a transformation such that the axis vertebra (C2) takes on morphological aspects of the atlas (C1). This also occurs when Hoxb-4 is misexpressed (Ramirez-Solis et al., 1993; Horan et al., 1995). As well, with misexpression of Hoxd4, supernumerary neural arches develop anteriorly between C1 and the occipital (Lufkin et al., 1992; Horan et al., 1995). Although not related to a homeotic transformation, the neural arches of $\mathrm{C} 1$ C3 can also become malformed and fused (Horan et al., 1995).

By comparison, deletion of Hoxd-3 results in a shift of the expression of Hoxd-3 posteriorly from somite 5 to somite 6 , resulting in the atlas coming to resemble parts of the occiput (Lufkin et al., 1992; Condie and Capecchi, 1993, 1994; Subramanian et al., 1995; van den Akker et al., 2002). For example, the lateral parts of the atlas are altered, becoming similar to the exoccipitals (and may fuse with these), while the anterior arch of the atlas is transformed into an extension of the basioccipital. The axis also takes on a morphology more comparable to the atlas (Condie and Capecchi, 1994). Moreover, Manley and Capecchi (1997) examined the effects of combined mutations in the Hox3 paralogues Hoxa-3, Hoxb-3 and Hoxd-3. Separate mutations in each gene show largely non-overlapping phenotypes, but unusually, in combinations of paralogue mutants, phenotypes appear that are not associated with single mutations of the gene. For example, a double homozygous mouse mutant (Hoxa- $3^{-/ /} / H_{0}$ xb $-3^{-/}$) showed changes to the atlas and occipital region that were similar to the phenotype produced by deletion of Hoxd-3 described above. These results suggested that a number of paralogous Hox genes acted together to regulate vertebral identity in mice (Manley and Capecchi, 1997). Notably, these changes occur at specific points in ontogeny, with the effects of Hoxd-4 misexpression occurring at mouse developmental stage E.14.5, but not at the earlier stage E.9.5 (Horan et al., 1995). Homeotic change resulting from temperature shocks affects mice at stage E7.5 (Li and Shiota, 1999) and those produced by retinoic acid at E10.5 (Kessel, 1992).

With respect to the placoderm Cowralepis, we suggest that a comparable event occurred during ontogenetic development, involving a mutation or mutations within the Hox3 paralogous group to produce a homeotic transformation of the synarcual to the morphology of the occipital. Our suggestions are based on the unusual morphological similarity between the occipital region and the anterior vertebral region (synarcual) in Cowralepis, and the general homology between anterior cervical regions of the vertebral column among vertebrates, as recognized by Burke et al. (1995), and discussed above.

However, it is important to note that a number of genes located upstream of the Hox clusters can affect Hox gene expression and also produce homeotic transformations in the anterior vertebral column (reviewed by Deschamps and van Nes, 2005; Howell et al., 2007). For example, misexpression of genes related to the Notch pathway affects Hox expression, resulting in homeotic shifts in vertebral identity comparable to the phenotypes described above (Zákány et al., 2001). Cdx genes are related to Hox genes and directly regulate Hox genes throughout the vertebral column (van den Akker et al., 2002; Deschamps and van Nes, 2005). Misexpression of the gene $C d x-1$ caused homeotic trans- 
formations from $\mathrm{C} 1$ through to the first lumbar (L1) vertebra by shifting the rostral boundaries of gene expression posteriorly (van den Akker et al., 2002). However, while misexpression of Hoxd3 and its paralogues causes restricted phenotypic change, that of $c d x-1$ is more general and occurs along the vertebral column (Subramanian et al., 1995).

Genetic pathways regulating anterior vertebral identity are complex, and relating fossil morphologies to the misexpression of particular genes is difficult, although this has recently been attempted with respect to the shifting identities of thoracic and lumbar regions of the vertebral column in Mesozoic mammals (Luo et al., 2007). We cannot directly test whether a certain phenotype was produced by misexpression of a particular Hox gene or paralogy group in placoderms, or whether a more upstream gene was involved; nevertheless the majority of genes resulting in homeotic mutations along the vertebral column are Hox genes or are regulating Hox genes (Howell et al., 2007). This, along with vertebral homologies among the Vertebrata, suggest that if the change in Cowralepis synarcual morphology is a homeotic mutation, then at some level a Hox gene(s) would have been involved.

\section{Hox genes in the stem-Gnathostomata}

Living jawed vertebrates (crown-group Gnathostomata) have four Hox gene clusters (HoxA-D), most recently demonstrated in the taxon Chondrichthyes (Venkatesh et al., 2007). To produce these four clusters, Hox gene duplications are hypothesized to have occurred through chordate history, from one cluster in cephalochordates (amphioxus; Garcia-Fernandez and Holland, 1994) to produce the four clusters characteristic of crown-group gnathostomes (Chondrichthyes + Osteichthyes and all descendants; Fig. 1). The question is, where did these duplication events occur within the extended phylogenetic history of the Vertebrata? As discussed below, hagfish and lampreys not only have independent Hox duplication events, but are separated from crown-group gnathostomes by a wide phylogenetic gap (Fig. 1). This gap is filled by a large number of fossil representatives of the stemGnathostomata, including the Placodermi. Donoghue and Purnell noted (2005: 317) "only data from stem taxa can resolve this issue [of gene duplication timing]. We are never going to be able to sequence any of their genes but it might be possible to constrain the timing of gen(om)e duplication by inferring the existence of new paralogues from evidence of their first phenotypic expression in fossils from within the stem (phenotypic expression being understood from studies of knockout, misexpression and in situ hybridization in extant crown group representatives)". We use this rationale to describe the presence of Hox genes and potential gene duplication in the Placodermi, although there are difficulties, as described below.

Although there is some disagreement, the $2 \mathrm{R}$ duplication model is generally favoured, in which Hox duplication would be part of two rounds of whole genome duplication, from one, to two, to four clusters (Ohno, 1970; Furlong and Holland, 2002; Panopoulou et al., 2003; Dehal and Boore, 2005; Panopoulou and Poustka, 2005; Blomme et al., 2006; Furlong etal., 2007; Venkatesh et al., 2007). However, complicating a scenario of straightforward duplication are the hagfish and lampreys (jawless vertebrates), resolved as the immediate outgroups to the total group Gnathostomata in current cladograms (Donoghue and Purnell,
2005). There appears to be a duplication event prior to the most recent common ancestor of hagfish and lampreys and the Gnathostomata (from one cluster to two), with independent duplication events occurring subsequently in both the hagfish and lamprey and deletion in the lamprey (Pendleton et al., 1993; Force et al., 2002; Fried et al., 2003; Stadler et al., 2004). A second duplication event was thought to occur after hagfish and lampreys diverged from the vertebrate lineage (reviewed in Panopoulou and Poustka, 2005), although Furlong et al. (2007) recently suggested that both rounds of duplication occurred after this divergence, based on data on the ParaHox cluster from the hagfish.

Panopoulou and Poustka (2005) suggested the timing of gene duplications could be estimated at between 320-650mya (a span of time extending from the late Precambrian through most of the Palaeozoic era), although they could not determine whether these duplication events occurred shortly after one another or if the second occurred much later. In fact, based on fossil evidence (except the lampreys and hagfish), the majority of vertebrate groups illustrated in Fig. 1 originate from the Cambrian to the Silurian (including all crown-group gnathostomes), and particularly in the Silurian (Janvier, 1996; 420-400mya). On this basis, the Hox duplication events to produce the four clusters seen in the crown-group gnathostomes must have occurred relatively rapidly after one another. It may be more relevant (in terms of gene duplications and related morphologies) to consider where these duplications occurred along the vertebrate phylogeny.

Following Donoghue and Purnell's (2005) suggestion to compare fossil phenotypes to those produced by gene misexpression in extant crown-group gnathostomes, our observations on the occipital and synarcual region of the placoderm Cowralepis indicate anatomical transformations that we relate to gene misexpression or deletion within the Hox3 paralogy group, specifically Hoxd-3, by comparison to transformations in mice (Lufkin et al., 1992). This suggests the presence of four separate HoxA$D$ clusters in the Placodermi and indicates that the second round of Hox gene duplication (2R) be placed at least at the node where the Placodermi are resolved in the gnathostome clade (Fig. 1).

However, such a straightforward interpretation is problematic because a second interpretation is possible, that the homeotic mutation proposed for Cowralepis was acting on Hox genes of the two-cluster stage formed after the first Hox gene duplication event (1R). The identity of the Hox genes within these clusters is uncertain (Bailey et al., 1997; Furlong and Holland, 2002), for example, Venkatesh et al. (2007) suggest these clusters comprised $(A B)(C D)$. Nevertheless, there is evidence that HoxA and HoxD were related in the Hox protoclusters (AD), based on evidence from regulatory elements associated with the tetrapod limb controlling HoxD expression. This regulatory element, the Global Control Region (GCR), controls a later phase of HoxD expression in the tetrapod limb (Tarachini and Duboule, 2006). A comparable late phase of HoxD expression has also recently been found in the fins of sharks (Freitas et al., 2007) and phylogenetically basal actinopterygians (Davis et al., 2007). This implies that the GCR is also present in these taxa. A GCR has also been found in association with the HoxA cluster (Lehoczky et al., 2004; Lee et al., 2006), suggesting that HoxA and HoxD clusters shared this as an ancestral condition in the protocluster prior to $2 \mathrm{R}$ duplication (Gonzalez et al., 2007). 
Force et al. (1999) described the DDC model (duplicationdegeneration-complementation), which predicted that prior to gene duplication, an ancestral gene and associated cis-regulatory elements will conserve multiple gene functions. After duplication, certain of these regulatory elements will be affected by mutation and degenerate, partitioning the ancestral gene functions between the duplicates (subfunctionalization). Or, the ancestral gene function can remain with one of the duplicates after duplication, with a new function developing in the other duplicate (neofunctionalization). With respect to the proposed Hox(AD) protocluster, subfunctionalization would predict that ancestral gene function would include components of HoxA and HoxD function. In the mouse, misexpression of HoxA affects the thymus, thyroid and parathyroid, while HoxD misexpression affects the craniocervical region (Manley and Capecchi, 1997). The ancestral gene representing the Hox(AD) cluster would combine these functions, controlled by different regulatory elements.

Although Donoghue and Purnell (2005) suggested that gene duplication could be recognized in the stem-Gnathostomata by comparing fossil morphologies to phenotypes produced by misexpression in extant taxa, our observations on the occipital and synarcual region of Cowralepis cannot predict whether a mutation occured in a separate HoxD cluster or in the regulatory element associated with the HoxD component of the Hox(AD) protocluster. Perhaps the second gene duplication event resulting in four separate Hox clusters can only be recognized in the fossil record when neofunctionalization occurs and a new function appears, resulting from a mutation in a duplicated regulatory region. This would produce a new phenotype that otherwise did not exist prior to duplication in the ancestral gene. Several new morphologies evolve within the stem-Gnathostomata (e.g., Donoghue and Purnell, 2005), and these may be the events that will shed more light on gene duplication in this region of vertebrate phylogeny.

\section{Conclusions}

Development of the synarcual in placoderms and chondrichthyans involves fusion of the anterior vertebral column and loss of various parts of the vertebrae. The synarcual of Cowralepis shows complete fusion of what are interpreted to be the neural and haemal arch bases; more distal portions of the neural and haemal arches and spines are absent (Fig. 2). The origin of the synarcual in extant taxa (Chondrichthyes) may be foreshadowed by the placoderm synarcual where differing morphologies and level of fusion correspond to morphologies produced in current misexpression experiments/observations involving several genes. This implies that the synarcual in extant chondrichthyans evolved as a result of gene misexpression that became fixed within certain groups, potentially including genes such as Pax-1, Zic, Gli-3 and Msx-1, Msx-2 (Figs. 2 L,M).

There are a myriad of genes involved in vertebral development and identity within the vertebral column, which can be investigated in humans (in the context of disease syndromes), mice and chickens, with potential comparisons to chondrichthyans. For example, the genome of the elephant shark Callorhinchus milli has recently been sequenced (Venkatesh et al., 2007). This will eventually allow suggestions made above with respect to gene expression and misexpression in Cowralepis to be more fully tested.
The presence of anatomical transformations either induced in experimental genetic studies or associated with human syndromes suggests a possible mechanism for the evolutionary origin of these structures in various taxa. The presence in fossil taxa provides clues to the timing of these evolutionary events and the origin of the genes associated with these transformations, within the stem-Gnathostomata, although difficulties described above still need to be resolved.

\section{Acknowledgements}

We would like to thank Alex McLachlan, owner of the property on which the quarry producing Cowralepis mclachlani is located. Mr. McLachlan has provided unlimited access to the quarry and substantial financial support. Volunteers organized by Gondwana Dreaming, Canberra, collected a large number of specimens over the years. RKC acknowledges support from a Visiting Research Fellowship from the Australian Museum, Sydney. We also thank Scott Schaefer for access to AMNH Ichthyology collections and especially thank Oliver Hampe and Jürgen Kriwet (Museum für Naturkunde, Berlin) for providing the photograph of Erromenosteus diensti.

\section{References}

ANDERSSON, J., JOHANSSON, F. and SÖDERLUND, T. (2006). Interactions between predator- and diet-induced phenotypic changes in body shape of crucian carp interactions between predator- and diet-induced phenotypic changes in body shape of crucian carp. Proc. R. Soc. B. Biol. Sci. 273: 431-437.

ARRATIA, G., SCHULTZE, H. -P. and CASCIOTTA. J. (2001). Vertebral column and associated elements in dipnoans and comparison with other fishes: Development and homology. J. Morph. 250: 101-172.

ARUGA, J. MIZUGISHIA, K., KOSEKIC, H., IMAID, K., BALLING, R., NODAE, T. and MIKOSHIBA, K. (1999). Zic1 regulates the patterning of vertebral arches in cooperation with Gli3. Mech. Dev. 89: 141-150.

BAILEY, W. J., KIM, J. WAGNER, G. P. and RUDDLE, F. H. (1997). Phylogenetic reconstruction of vertebrate Hox cluster duplications. Mol. Biol. Evol. 14: 843853.

BATESON, W. (1894). Materials for the study of variation treated with special regard to discontinuity in the origin of species. Macmillan, London.

BEMIS, W. E. and FOREY, P. L. (2001). Occipital structure and the posterior limit of the skull in actinopterygians. In Major Events in Early Vertebrate Evolution (ed. P. Ahlberg). Taylor and Francis, London, pp. 41-62.

BLOMME, T., VANDEPOELE, K., DE BODT, S., SIMILLION, C., MAERE, S. and VAN DE PEER, Y. (2006). The gain and loss of genes during 600 million years of vertebrate evolution. Genome Biol. 7: R43.1-R43.12.

BRÖNMARK, C. and MINER, J. G. (1992). Predator-induced phenotypical change in body morphology in crucian carp. Science 258: 1348-1350

BURKE, A. C., NELSON, C. E., MORGAN, B. A. and TABIN C. (1995). Hox genes and the evolution of vertebrate axial morphology. Development 121: 333-346.

CARR, R.K., JOHANSON, Z. and RITCHIE, A. (2009). The phyllolepid placoderm Cowralepis mclachlani: Insights into the evolution of feeding mechanisms in jawed vertebrates. J. Morphology 270: 775-804

CHIVERS, D. P., ZHAO, X., BROWN, G. E., MARCHANT, T. A. and FERRARI, M. C. O. (2008). Predator-induced changes in morphology of a prey fish: the effects of food level and temporal frequency of predation risk. Evol. Ecol. 22: 561-574.

CHRIST, B., HUANG, R. and WILTING, J. (2000). The development of the avian vertebral column. Anat. Embryol. 202: 179-194.

CONDIE, B. G. and CAPPECHI, M. (1993). Mice homozygous for a targeted disruption of Hoxd-3 (Hox-4.1) exhibit anterior transformations of the first and second cervical vertebrae, the atlas and the axis. Development 119: 579-595.

CONDIE, B. G. and CAPPECHI, M. (1994). Mice with targeted disruptions in the paralogous genes Hoxa-3 and Hoxd-3 reveal synergistic reactions. Nature 370 : 304-307.

DAVIS, M. C., DAHN, R. D. and SHUBIN, N. H. (2007). An autopodial-like pattern of Hox expression in the fins of a basal actinopterygian fish. Nature 447: 473-476. 
DE BEER, G. (1971). The Development of the Vertebrate Skull. Clarendon Press, Oxford.

DEHAL, P. and BOORE, J. L. (2005). Two rounds of whole genome duplication in the ancestral vertebrate. PLOS Biol. 3: e314.

DENISON, R. (1978). Handbook of Paleoichthyology, Vol. 2, Placodermi. Gustav Fischer Verlag, New York.

DESCHAMPS, J. and VAN NES, J. (2005). Developmental regulation of the Hox genes during axial morphogenesis in the mouse. Development 132: 2931-2942.

DIDIER, D. A. (1995). Phylogenetic systematics of extant chimaeroid fishes (Holocephali, Chimaeroidei). Am. Mus. Novit. 3119: 1- 86.

DIPAOLA, C. P., FARMER, J. C., MANOVA, K. and NISWANDER, L. A. (2005). Molecular signaling in intervertebral disk development. J. Orthopaedic Res. 23: 1112-1119.

DONOGHUE, P. C. J. and PURNELL, M. A. (2005). Genomic duplication, extinction and vertebrate evolution. Trends Ecol. Evol. 20: 312-319.

FAVIER, B. and DOLLE, P. (1997). Developmental functions of mammalian Hox genes. Mol. Human Reprod. 3: 115-131.

FORCE, A., LYNCH, M., PICKETT, F. B., AMORES, A., YAN, Y. -L., and POSTLETHWAIT, J. (1999). Preservation of duplicate genes by complementary, degenerative mutations. Genetics 151: 1531-1545.

FORCE, A., AMORES, A. and POSTLETHWAIT, J. H. (2002). Hox cluster organization in the jawless vertebrate Petromyzon marinus. J. Exp. Zool. 294: 30-46.

FREITAS, R., ZHANG, G. and COHN, M. J. (2007). Biphasic Hoxd gene expression in shark paired fins reveals an ancient origin of the distal limb domain. PLOS ONE 15: e754.

FRIED, C., PROHASKA, S. J. and STADLER, P. F. (2003). Independent Hoxcluster duplications in lampreys. J. Exp. Zool. B Mol. Dev. Evol. 299: 18-25.

FURLONG, R. F. and HOLLAND, P. W. H. (2002). Were vertebrates octoploid? Phil. Trans. R. Soc. Lond. B 357: 531-544.

FURLONG, R. F., YOUNGER, R., KASAHARA, M., REINHARDT, R., THORNDYKE, M. and HOLLAND, P. W. H. (2007). A degenerate ParaHox gene cluster in a degenerate vertebrate. Mol. Biol. Evol. 24: 2681-2686

GARCIA-FERNANDEZ, J. and HOLLAND, P. W. (1994). Archetypal organization of the amphioxus hox gene cluster. Nature 370: 563-566.

GONZALEZ, F., DUBOULE, D. and SPITZ, F. (2007). Transgenic analysis of Hoxd regulation during digit development. Dev. Biol. 306: 847-859.

GONZÁLEZ-ISÁIS, M. and MONES DOMINGUEZ, H. M. (2004). Comparative anatomy of the superfamily Myliobatoidea (Chondrichthyes) with some comments on phylogeny. J. Morphol. 262: 517-535.

GORMAN, K. F. and BREDEN, F. (2007). Teleosts as models for human vertebral stability and deformity. Comp. Biochem. Phys. C. 145: 28-38.

GROTMOL, S., KRYVI, H., NORDVIK, K. and TOTLAND, G. K. (2003). Notochord segmentation may lay down the pathway for the development of the vertebral bodies in the Atlantic salmon. Anat. Embryol. 207: 263-272.

HOWELL, G. R., SHINDO, M., MURRAY, S., GRIDLEY, T., WILSON, L. A. and SCHIMENTI, J. C. (2007). Mutation of a ubiquitously expressed mouse transmembrane protein (Tapt1) causes specific skeletal homeotic transformations. Genetics 175: 699-707.

HORAN, G. S., RAMÍREZ-SOLIS, R., FEATHERSTONE, M. S., WOLGEMUTH, D. J.,ÄBRADLEY, A. and BEHRINGER, R. R. (1995). Compound mutants for the paralogous hoxa-4, hoxb-4, and hoxd-4 genes show more complete homeotic transformations and a dose-dependent increase in the number of vertebrae transformed. Genes Dev. 9: 1667-1677.

JANVIER, P. (1996). Early Vertebrates. University of Oxford Press, Oxford.

JANVIER, P. and ARSENAULT, M. (2007). The anatomy of Euphanerops longaevus Woodward, 1900, an anaspid-like jawless vertebrate from the Upper Devonian of Miguasha, Quebec, Canada. Geodiversitas 29: 143-216.

KARDONG, K. V. (2002). Vertebrates: Comparative Anatomy, Function, 3rd ed. McGraw-Hill, Boston.

KESSEL, M. (1992). Respecification of vertebral identities by retinoic acid. Development 118: 487-501.

KESSEL, M., BALLING, R. and GRUSS, P. (1990). Variations of cervical vertebrae after expression of a Hox-1.1 transgene in mice. Cell 61: 301-308.

KURATANI, S. (2005). Developmental studies on the vertebrate head evolution.
Zool. Sci. 22:1361-1366.

LEHOCZKY, J. A., WILLIAMS, M. E. and INNIS, J. W. (2004). Conserved expression domains for genes upstream and within the HoxA and HoxD clusters suggests a long-range enhancer existed before cluster duplication. Evol. Dev. 6: $423-430$.

LEE, A. P., KOH, E. G. K., TAY, A., BRENNER, S. and VENKATESH, B. (2006). Highly conserved syntenic blocks at the vertebrate Hox loci and conserved regulatory elements within and outside Hox gene clusters. Proc. Natl. Acad. Sci. USA 103: 6994-6999.

LELIÈVRE, H. and CARR, R. C. (2009). The occipital-synarcual complex in Nefudina qalibahensis. J. Vert.Paleo. 29: 584-588.

LI, Z. -L. and SHIOTA, K. (1999). Stage-specific homeotic vertebral transformations in mouse fetuses induced by maternal hyperthermia during somitogenesis. Dev. Dyn. 216: 336-348.

LONG, J. A. (1997). Ptyctodontid fishes (Vertebrata, Placodermi) from the Late Devonian Gogo Formation, Western Australia, with a revision of the European genus Ctenurella Orvig, 1960. Geodiversitas 19: 515-555.

LUFKIN, T., MARK, M., HART, C. P., DOLLE, P., LEMEUR, M. and CHAMBON, P. (1992). Homeotic transformation of the occipital bones of the skull by ectopic expression of a homeobox gene. Nature 359: 835-841.

LUO, Z. -X. CHEN, P., LI, G. and CHEN, M. (2007). A new eutriconodont mammal and evolutionary development in early mammals. Nature 446: 288-293.

MANLEY, N. R. and CAPECCHI, M. R. (1997). Hox Group 3 paralogous genes act synergistically in the formation of somitic and neural crest-derived structures. Dev. Biol. 192: 274-288.

MATSUOKA, T., AHLBERG, P. E., KESSARIS, N., IANNARELLI, P., DENNEHY, U., RICHARDSON, W. D., MCMAHON, A. P. and KOENTGES, G. (2005). Neural crest origins of the neck and shoulder. Nature 436: 347-355.

MCGAUGHRAN, J. M., OATES, A., DONNAI, D., READ, A. P.-and TASSABEHJI, M. (2003). Mutations in PAX1 may be associated with Klippel-Feil syndrome. Eur. J. Hum. Genet. 11: 468-474

MILES, R. S. and YOUNG, G. C. (1977). Placoderm interrelationships reconsidered in the light of new ptyctodontids from Gogo, Western Australia. In Problems in Vertebrate Evolution (eds. Andrews, S. M., Miles, R. S. \& Walker, A. D.) Linnean Society, London, pp. 123-198.

MONSORO-BURQ, A. H. (2005). Sclerotome development and morphogenesis: when experimental embryology meets genetics. Int. J. Dev. Biol. 49: 301-308.

MONSORO-BURQ, A. H., BONTOUX, M., TEILLET, M. A. and LE DOUARIN, N (1994). Heterogeneity in the development of the vertebra. Proc. Natl. Acad. Sci. USA 22: 10435-10439.

OHNO, S. (1970). Evolution by Gene Duplication. Springer-Verlag, New York.

PANOPOULOU, G., HENNIG, S., GROTH, D., KRAUSE, A., POUSTKA, A. J., HERWIG, R., VINGRON, M. and LEHRACH, H. (2003). New evidence for genome-wide duplications at the origin of vertebrates using an amphioxus gene set and completed animal genomes. Genome Res. 13: 1056-1066.

PANOPOULOU, G. and POUSTKA, A. J. (2005). Timing and mechanism of ancient vertebrate genome duplications - the adventure of a hypothesis. Trends Genetics 21: 559-567.

PENDLETON, J. W., NAGAI, B. K., MURTHA, M. T. and RUDDLE, F. H. (1993) Expansion of the Hox gene family and the evolution of chordates. Proc. Natl. Acad. Sci. USA 90: 6300-6304.

PETERS, H., WILM, B., SAKAI, N., IMAI, K., MAAS, R. and BALLING, R. (1999). Pax1 and Pax9 synergistically regulate vertebral column development. Development 126: 5399-5408.

RAMÍREZ-SOLIS, R., ZHENG, H., WHITING, J., KRUMLAUF, R. and BRADLEY, A. (1993). Hoxb-4 (Hox-2.6) mutant mice show homeotic transformation of a cervical vertebra and defects in the closure of the sternal rudiments. Cell 73 : 279-294

RITCHIE, A. (2005). Cowralepis, a new genus of phyllolepid fish (Pisces, Placodermi) from the Late Middle Devonian of New South Wales, Australia. Proc. Linn. Soc. N.S.W. 126: 215-259.

SAMARTZSIS, D. D., HERMAN, J., LUBICKY, J. P. and SHEN, F. H. (2006) Classification of congenitally fused cervical patterns in Klippel-Feil patients: epidemiology and role in the development of cervical spine-related symptoms. Spine 31: E798-804 


\section{Z. Johanson et al.}

SCHAFFER, A. A., KAPLAN, F. S., TRACY, M. R., O'BRIEN, M. L., DORMANS, J. P. SHORE, E. M., HARLAND, R. M. and KUSUMI, K. (2005). Developmental anomalies of the cervical spine in patients with Fibrodysplasia Ossificans Progressiva are distinctly different from those in patients with Klippel-Feil Syndrome. Spine 30: 1379-1385.

STADLER, P. F., FRIED, C., PROHASKA, S. J., BAILEY, W. J., MISOF, B. Y., RUDDLE, F. H. AND WAGNER, G. P. (2004). Evidence for independent Hox gene duplications in the hagfish lineage: a PCR-based gene inventory of Eptatretus stoutii. Mol. Phylogenet. Evol. 32: 686-694.

STENSIÖ, E. A. (1963). Anatomical studies on the arthrodiran head. Kungl. Sven. Vetenskap. Handl. 9: 1-419.

STORRE, J., ELSASSER, H. P., FUCHS, M., ULLMANN, D., LIVINGSTON, D. M. and GAUBATZ, S. (2002). Homeotic transformations of the axial skeleton that accompany a targeted deletion of E2f6. EMBO Rep. 3: 695-700.

SUBRAMANIAN, V., MEYER, B L. and GRUSS, P. (1995). Disruption of the murine Homeobox gene $C d x 1$ affects axial skeletal identities by altering the mesodermal expression domains of Hox genes. Cell 63: 641-653.

TARACHINI, B. and DUBOULE, D. (2006). Control of Hoxd genes' collinearity during early limb development. Dev. Cell 10: 93-103.

TRACY, M. R., DORMANS, J. P. and KUSUMI, K. (2004). Klippel-Feil syndrome: clinical features and current understanding of etiology. Clin. Orthop. Relat. Res. 424: 183-90.

TURNPENNY, P. D., ALMAN, B., CORNIER, A. S., GIAMPIETRO, P. F., OFFIAH, A., TASSY, O., POURQUIE, O., KUSUMI, K. and DUNWOODIE, S. (2007). Abnormal vertebral segmentation and the notch signaling pathway in man. Dev. Dyn. 236: 1456-1474.
VAN DEN AKKER, E., FORLANI, S., CHAWENGSAKSOPHAK, K,. DE GRAAFF, W., BECK, F., MEYER, B. I., and DESCHAMPS, J. (2002). Cdx1 and Cdx2 have overlapping functions in anteroposterior patterning and posterior axis elongation. Development 129: 2181-2193.

VENKATESH, B., KIRKNESS, E. F., LOH, Y. H., HALPERN, A. L., LEE, A. P., JOHNSON, J., DANDONA, N., VISWANATHAN, L. D., TAY, A., VENTER, J. C., STRAUSBERG, R. L. and BRENNER, S. (2007). Survey sequencing and comparative analysis of the elephant shark (Callorhinchus milii) genome. PLoS Biol. 5: e101.

WALLIN, J., WILTING, J., KOSEKI, H., FRITSCH, R. CHRIST, B. and BALLING, R. (1995). The role of Pax-1 in axial skeleton development. Development 120 1109-1121.

WATANABE, Y., DUPREZ, D., MONSORO-BURQ, A. H., VINCENT, C. and LE DOUARIN, N. M. (1998). Two domains in vertebral development: antagonistic regulation by SHH and BMP4 proteins. Development 125: 2631-2639.

WELLIK, D. M. (2007). Hox patterning of the vertebrate axial skeleton. Dev. Dyn. 236: 2454-2463.

WINTZER, A. P. and MOTTA, P. J. (2005). Diet-induced phenotypic plasticity in the skull morphology of hatchery-reared Florida largemouth bass, Micropterus salmoides floridanus. Ecol.Freshwater Fish 14: 311-318.

YOUNG G. C. (1979). New information on the structure and relationships of Buchanosteus (Placodermi, Euarthrodira) from the Early Devonian of New South Wales. Zool. J. Linn. Soc. 66: 309-352.

ZÁKÁNY, J., KMITA, M., ALARCON, P., DE LA POMPA, J. L. and DUBOULE, D. (2001). Localized and transient transcription of Hox genes suggests a link between patterning and the segmentation clock. Cell 106: 207-217. 


\section{Further Related Reading, published previously in the Int. J. Dev. Biol.}

See our recent Special Issue Fertilization, in honor of David L. Garbers and edited by Paul M. Wassarman and Victor D. Vacquier at: http://www.ijdb.ehu.es/web/contents.php?vol=52\&issue=5-6

Regulation and function of Spalt proteins during animal development Jose F. de Celis and Rosa Barrio Int. J. Dev. Biol. (2009) 53: 1385-1398 (doi: 10.1387/ijdb.072408jd)

Non-genic transcription at the Drosophila bithorax complex - functional activity of the dark matter of the genome Margaret C.W. Ho, Benjamin J. Schiller, Sara E. Goetz and Robert A. Drewell Int. J. Dev. Biol. (2009) 53: 459-468

Fate of cranial neural crest cells during craniofacial development in endothelin-A receptor-deficient mice

Makoto Abe, Louis-Bruno Ruest and David E. Clouthier

Int. J. Dev. Biol. (2007) 51: 97-105

The Drosophila pleiohomeotic mutation enhances the Polycomblike and Polycomb mutant phenotypes during embryogenesis and in the adult

Seung-Hae Kwon, Sang Hee Kim, Hae-Moon Chung, Jack R Girton and Sang-Hak Jeon Int. J. Dev. Biol. (2003) 47: 389-395

Differentiation and growth of kype skeletal tissues in anadromous male Atlantic salmon (Salmo salar)

$\mathrm{P}$ Eckhard Witten and Brian $\mathrm{K}$ Hall

Int. J. Dev. Biol. (2002) 46: 719-730

Developmental control of chondrogenesis and osteogenesis

R Cancedda, P Castagnola, F D Cancedda, B Dozin and R Quarto

Int. J. Dev. Biol. (2000) 44: 707-714

Hox genes, homeosis and the evolution of segment identity: no need for hopeless monsters

M Akam

Int. J. Dev. Biol. (1998) 42: 445-451

The formation of somite compartments in the avian embryo

B Brand-Saberi, J Wilting, C Ebensperger and B Christ

Int. J. Dev. Biol. (1996) 40: 411-420

The puzzle of Hox genes

A E Carrasco and S L López

Int. J. Dev. Biol. (1994) 38: 557-564

Development of the notochord in normal and malformed human embryos and fetuses M S Babic

Int. J. Dev. Biol. (1991) 35: 345-352

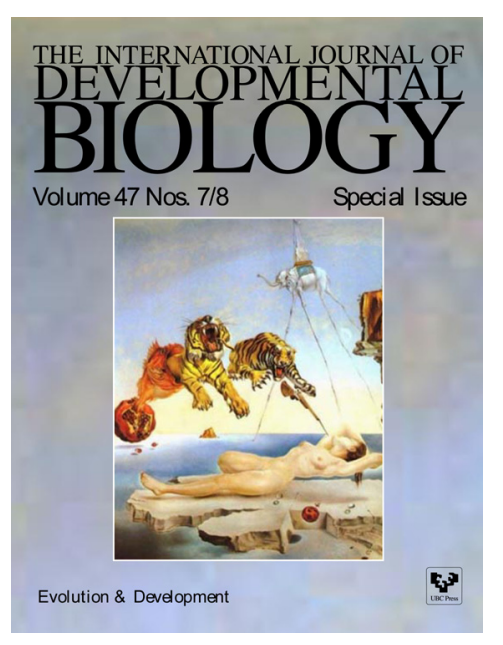

5 yr ISI Impact Factor $(2008)=3.271$

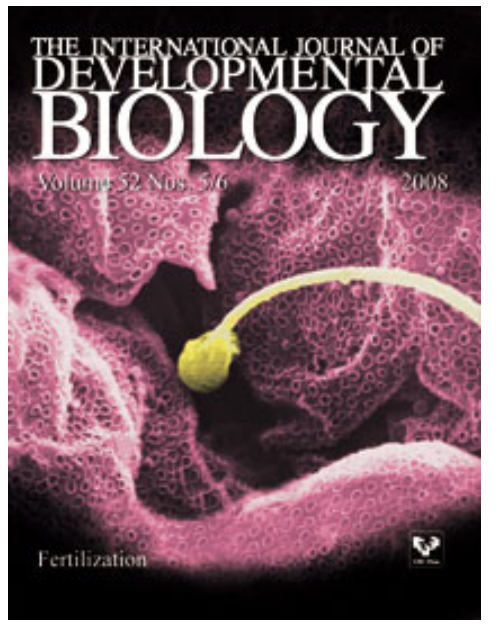

